\title{
Selection for B cells with productive IgL gene rearrangements occurs in the bursa of Fabricius during chicken embryonic development
}

\author{
Wayne T. McCormack, ${ }^{1,3}$ Larry W. Tjoelker, ${ }^{2}$ Carolyn F. Barth, ${ }^{4}$ Louise M. Carlson, ${ }^{1}$ \\ Bronislawa Petryniak, ${ }^{1}$ Eric H. Humphries, ${ }^{4}$ and Craig B. Thompson ${ }^{1-3}$ \\ ${ }^{1}$ Howard Hughes Medical Institute, ${ }^{2}$ Departments of Microbiology and Immunology and ${ }^{3}$ Internal Medicine, University of \\ Michigan Medical School, Ann Arbor, Michigan 48109 USA; ${ }^{4}$ Department of Microbiology, University of Texas Southwestern \\ Medical Center, Dallas, Texas 75235 USA
}

The vast majority of immunoglobulin-expressing mature chicken B lymphocytes contain one functionally rearranged and one unrearranged allele of the immunoglobulin light chain $\left(\operatorname{Ig}_{\mathrm{L}}\right)$ gene. Therefore, nearly all $\mathrm{Ig}_{\mathrm{L}}$ V-J rearrangements present in mature chickens are in-frame. In contrast, the Ig genes of mature mammalian B cells contain a high proportion of out-of-frame V-J joints. To investigate the basis for this difference, gene rearrangement at the chicken $\operatorname{Ig}_{\mathrm{L}}$ locus was characterized during embryonic development and in mature B-cell lines. Joining of the single functional variable $\left(V_{L}\right)$ segment with the single joining $\left(J_{L}\right)$ segment occurs in cells in multiple tissues during a transient period of chicken embryogenesis. Only one-third of the V-J joints cloned from days 10-12 of development are in-frame. An increasing proportion of in-frame V-J joints is observed within the bursa of Fabricius at successively later stages of development. Our data suggest that the bursa of Fabricius serves during embryonic development as a site of selective amplification of cells that have undergone productive V-J joining, such that nearly all V-J joints present in postembryonic B cells are in-frame. The high frequency of rearranged alleles joined in-frame that is found in posthatching bursal cells and mature B-cell lines appears to result from a low frequency with which cells undergo $\mathrm{Ig}_{\mathrm{L}}$ rearrangement at both alleles, rather than from an increase in the precision of $\mathbf{V}-\mathrm{J}$ joining in avian species.

[Key Words: Allelic exclusion; bursa of Fabricius; chicken; gene rearrangement; immunoglobulin genes]

Received January 16, 1989; revised version accepted March 20, 1989.

The germ-line immunoglobulin light chain $\left(\operatorname{Ig}_{\mathrm{L}}\right)$ locus in the chicken includes single functional variable $\left(V_{L}\right)$, joining $\left(J_{L}\right)$, and constant $\left(C_{L}\right)$ gene segments (Reynaud et al. 1985). Therefore, all chicken light chains are encoded by the same $\mathrm{V}_{\mathrm{L}}$ and $\mathrm{J}_{\mathrm{L}}$ gene segments, which have been joined in-frame during $\mathrm{Ig}_{\mathrm{L}}$ gene rearrangement. Whereas some junctional diversity may be generated by V-J joining, more extensive diversity is introduced into the rearranged $V_{L}$ gene segments by somatic gene-conversion events. These gene conversions use an upstream family of $25 V_{L}$ pseudogenes as sequence donors and occur in the bursa of Fabricius during a specific stage of B-cell development (Reynaud et al. 1987; Thompson and Neiman 1987).

Joining of $\mathrm{V}_{\mathrm{L}}$ and $\mathrm{J}_{\mathrm{L}}$ gene-coding segments in mammals appears to be a random process. Because of the junctional diversity that results from V-J joining (Tonegawa 1983), only one-third of the V-J joints made in mammalian pre-B cells are in the correct translational reading frame (Engler and Storb 1988). In the murine system, rearrangement of the Ig loci in most B lymphocytes is be- lieved to occur sequentially $(\mathrm{H} \rightarrow \mathrm{\kappa} \rightarrow \lambda$ ) and be regulated by feedback inhibition, such that further rearrangement of light-chain genes is halted upon synthesis of complete Ig molecules (reviewed by Yancopoulos and Alt 1986). Some $\mathrm{Ig}_{\mathrm{A}}$-expressing B cells, on the other hand, do not appear to show feedback inhibition of gene rearrangements (Gollahon et al. 1988).

By analogy with mammalian B cells, only one-third of chicken $B$ cells might be expected to produce a functionally rearranged $\operatorname{Ig}_{\mathrm{L}}$ gene as a result of their first rearrangement. If feedback inhibition regulates chicken $\operatorname{Ig}_{L}$ gene rearrangement, those cells would cease $\mathrm{Ig}_{\mathrm{L}}$ rearrangements. Of the remaining two-thirds, an additional one-third might be expected to create a functional $\operatorname{Ig}_{\mathrm{L}}$ gene upon rearrangement of their second allele. A complete lack of feedback inhibition would result in rearrangement at both alleles in all chicken B cells. According to either mechanism of regulation, quantitation of the percentages of rearranged and germ-line alleles in a polyclonal population of surface Ig-expressing $\left(\mathrm{sIg}^{+}\right)$ chicken B cells would be expected to show an excess of 
rearranged alleles in the absence of a deletional mechanism to remove nonfunctional rearranged ${\operatorname{~} g_{L}}_{\text {genes. }}$ However, it was found that only $50 \pm 5 \%$ of the $\operatorname{Ig}_{\mathrm{L}}$ genes in a polyclonal sIg ${ }^{+}$population of bursal lymphocytes from 4- to 6-week-old birds are rearranged (Reynaud et al. 1985; Thompson and Nieman 1987). Based on this analysis, the vast majority of $\operatorname{sIg}^{+}$bursal lymphocytes appear to contain one functionally rearranged allele and one unrearranged allele, suggesting that nearly all $\mathrm{Ig}_{\mathrm{L}}$ rearrangements present after the bursal stage of B-cell development are functional.

These observations suggested that there may be differences in the regulation of Ig gene rearrangement between chicken and mammalian B cells. One possible explanation for the observed differences may be that rearrangement of both chicken $\mathrm{Ig}_{\mathrm{L}}$ loci is not compatible with cell viability. For example, rearrangement of both alleles might delete both copies of an essential sequence element lying between $V_{L}$ and $J_{L}$. Cells in which both alleles were rearranged would be viable only if a copy of this sequence were reintegrated into the genomic DNA. Alternatively, avian V-J joining may be much more precisely controlled than mammalian V-J joining, perhaps because of the close proximity $(1.8 \mathrm{~kb})$ of the unique $\mathrm{V}_{\mathrm{L}}$ and $\mathrm{I}_{\mathrm{L}}$ elements. This increased precision might result in the production of mostly in-frame V-J joints. Finally, it is possible that $\mathrm{Ig}_{\mathrm{L}}$ gene rearrangement may occur only during a limited period of B-cell development such that the majority of B cells would only have time to rearrange one $\mathrm{Ig}_{\mathrm{L}}$ allele. Only cells that rearranged the $\mathrm{Ig}_{\mathrm{L}}$ allele productively would be capable of completing B-cell differentiation.

Here we report a molecular analysis of chicken V-J joining events during development to address these issues. The rearrangement status of the $\mathrm{Ig}_{\mathrm{L}}$ locus in polyclonal bursal lymphocyte populations at various stages of development and in cell lines representing mature B cells was determined by Southern blot analysis. The timing of $\mathrm{Ig}_{\mathrm{L}}$ gene rearrangement events during embryogenesis was investigated by comparing the relative abundance of the signal joint episome deleted during V-J joining at different developmental stages. Finally, V-J junctions were sequenced to determine the proportion of productive versus nonproductive $\operatorname{Ig}_{\mathrm{L}}$ gene rearrangements present in the bursa of Fabricius at each developmental stage. Nucleotide sequences of V-J joints at the earliest stage of embryonic development examined revealed that two thirds of the V-J joints are out-of-frame. During the expansion of $B$ cells in the bursa of Fabricius, there was a marked increase in the percentage of rearranged alleles that are in-frame. This enrichment occurs prior to the initiation of gene conversion, suggesting that the enrichment results from a cell selection process rather than correction of out-of-frame joints by gene conversion. These experiments suggest a model for chicken B-cell differentiation in which there is a limited period of development during which Ig gene rearrangement occurs. During embryogenesis, the bursa of Fabricius serves both to selectively amplify B cells with productive Ig gene rearrangements and to activate the gene conversion process.

\section{Results}

\section{Rearrangement status of $I g_{L}$ loci during development}

The organization of the germ-line and rearranged chicken $\mathrm{Ig}_{\mathrm{L}}$ locus is shown in Figure 1A. Southern blot analysis of bursal lymphocyte DNA digested with the enzyme $B c l I$ and hybridized with the $\mathrm{C}_{\mathrm{L}}$ probe distinguishes between the germ-line and rearranged $\operatorname{Ig}_{\mathrm{L}}$ alleles. The $10.2-\mathrm{kb}$ germ-line fragment is reduced to an $8.4-\mathrm{kb}$ fragment during the V-J joining process. The rearranged allele is first detectable in the bursa by Southern blot analysis at day 15 of embryonic development (Fig. 1B). Cells with rearranged $\operatorname{~} g_{\mathrm{L}}$ alleles cannot be detected by Southern blot analysis in peripheral lymphoid organs such as the spleen until after hatching (Fig. 1B).

Between day 18 of embryogenesis and 2 weeks posthatching, all chicken B cells undergo a period of development within the bursa of Fabricius (Ratcliffe 1985). Lydyard et al. (1976) have shown that even at 18 days, the start of the period of bursa-dependent B-cell development, virtually all bursal lymphocytes express sIg. We find that by day 18 of embryonic development and at later stages, the germ-line and rearranged $B c l$ fragments of the $\mathrm{Ig}_{\mathrm{L}}$ gene appear at equal hybridization intensities (Fig. 1B). As described previously for $\mathrm{sIg}^{+}$bursal lymphocytes at 4-6 weeks of age, this result has been interpreted to suggest that most bursal lymphocytes rearrange only one allele (Reynaud et al. 1985; Thompson and Neiman 1987). To support this conclusion, we have analyzed 48 clonal chicken mature B-cell lines or tumors for their $\operatorname{Ig}_{\mathrm{L}}$ rearrangement status (Table 1). Thirty sIg ${ }^{+}$B-cell lymphomas derived by transformation with a v-rel-containing retrovirus were analyzed. Twenty-seven were found to have one germ-line and one rearranged allele. Only three v-rel-transformed cell lines had both $\operatorname{Ig}_{\mathrm{L}}$ alleles rearranged. In addition, $18 \mathrm{sIg}^{+}$ bursal lymphomas induced by avian leukosis virus (ALV) integration adjacent to c-myc were analyzed. All were found to have one rearranged and one germ-line allele at the $\operatorname{Ig}_{\mathrm{L}}$ locus. Therefore, 94\% (45/48) of the clonal $\mathrm{sIg}^{+}$chicken B-cell lines or tumors examined rearranged only one $\operatorname{Ig}_{\mathrm{L}}$ allele.

\section{The region between $V_{L}$ and $I_{L}$ is nonessential}

The availability of the three cell lines with two rearranged $I_{L}$ alleles provided an opportunity to evaluate the possibility that the DNA region between $V_{L}$ and $J_{L}$ is required for cell viability. If this were the case, we would expect to find one copy of the intervening DNA for a portion of it) reintegrated into the genome of cells with rearrangement of both $\mathrm{Ig}_{\mathrm{L}}$ alleles. Such reintegration at random positions in the genome would not be detectable in DNA prepared from a polyclonal population of chicken B cells. The rearrangement status of five v-rel- 
McCormack et al.
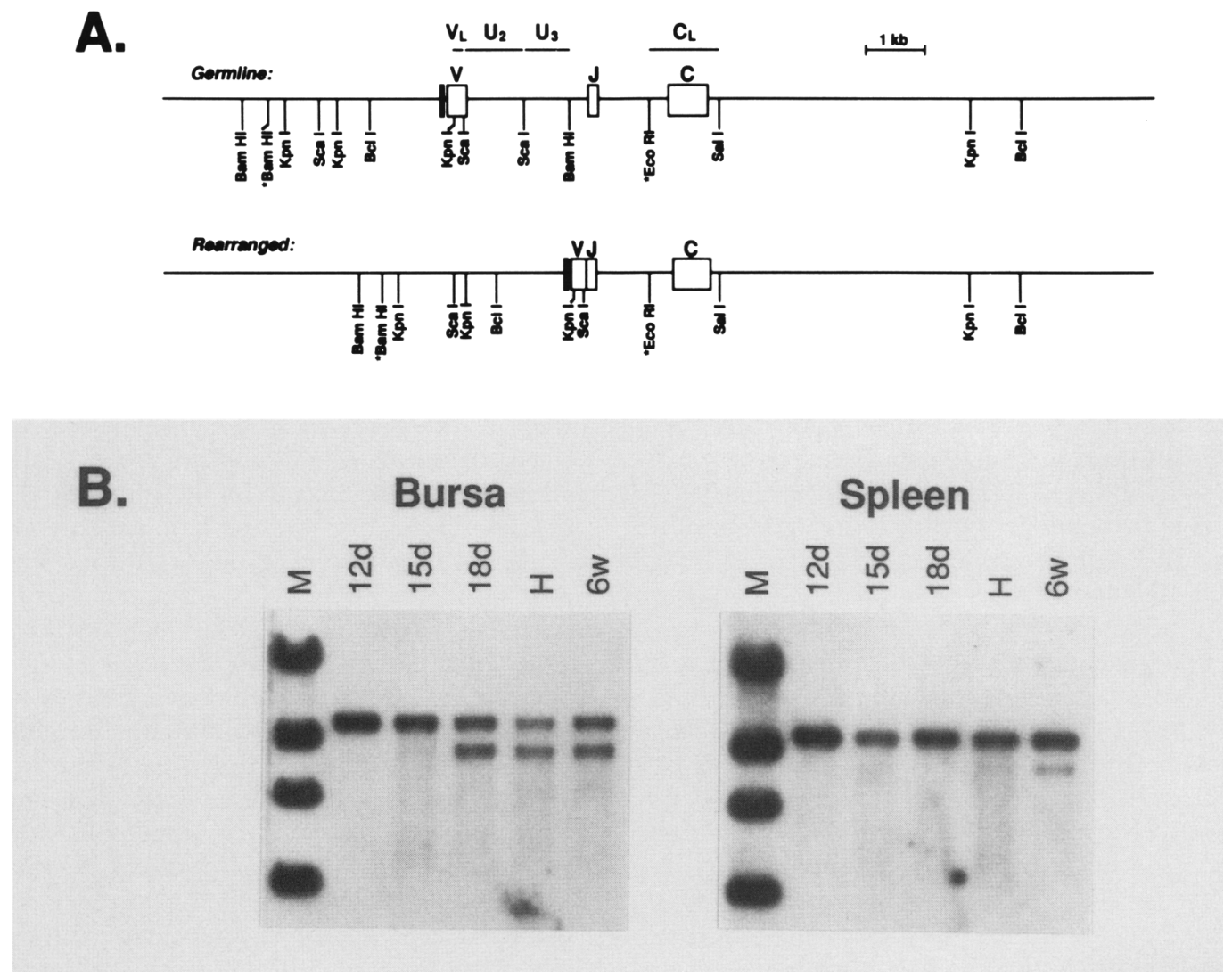

Figure 1. Organization of the germ-line and rearranged chicken $\operatorname{Ig}_{\mathrm{L}}$ locus. $(A)$ Restriction maps of the germ-line and rearranged $\mathrm{Ig}_{\mathrm{L}}$ alleles of the SC chicken. Exons are indicated by open boxes, and flanking sequence and introns are shown as lines. BamHI" and EcoRI* restriction site polymorphisms distinguish the two alleles. Both sites are present on one allele and absent from the other. Solid bars above the maps indicate the locations of hybridization probes. $(B)$ DNA samples from bursal and splenic tissue of a day-12 embryo and from bursal and splenic cells of day-15, day-18, day-of-hatch, and 6-week-old SC birds were digested with the enzyme BclI. Southern blots of these samples were hybridized with the $C_{I}$ probe. The resulting autoradiograms are shown. Marker bands $(M)$ are the end-labeled fragments of phage $\lambda$ DNA digested with HindIII (top to bottom): $23.1,9.4,6.7$, and $4.4 \mathrm{~kb}$.

induced bursal lymphomas is shown in Figure $2 \mathrm{~A}$. The three cell lines that rearranged both $\mathrm{Ig}_{\mathrm{L}}$ alleles are shown in lanes 2,3 , and 5 . Two cell lines that rearranged one $\mathrm{Ig}_{\mathrm{L}}$ allele (lanes 1 and 4 ) and bursal lymphocyte DNA from 6-week-old birds (lane 6) were included for comparison. When the Southern blot was reprobed with probes span-

Table 1. $I g_{L}$ rearrangement status of chicken B-cell lines

\begin{tabular}{lrr}
\hline Cell lines & \multicolumn{1}{l}{ GR } & \multicolumn{1}{c}{ RR } \\
\hline REV-T & $90 \%(27 / 30)$ & $10 \%(3 / 30)$ \\
ALV & $100 \%(18 / 18)$ & $0 \%(0 / 18)$ \\
Total & $94 \%(45 / 48)$ & $6 \%(3 / 48)$ \\
\hline
\end{tabular}

The $\mathrm{Ig}_{\mathrm{L}}$ rearrangement status of chicken B-cell lines generated by reticuloendotheliosis virus strain $\mathrm{T}$ infection (REV-T; Barth and Humphries 1988) and chicken B-cell lymphomas caused by avian leukosis virus integration (ALV; Thompson et al. 1987) was determined as described in Fig. 1 . The percentages of cell lines with one germ-line and one rearranged (GR) and with two rearranged (RR) $\mathrm{Ig}_{\mathrm{L}}$ alleles are shown. The number of cell lines analyzed is given in parentheses. ning the region of DNA between $V_{L}$ and $J_{L}$, hybridization was observed to the germ-line fragment of the cell lines with one rearranged allele (Fig. 2B). However, these probes did not hybridize to DNA from the three cell lines that rearranged both $\operatorname{~gg}_{\mathrm{L}}$ alleles (lanes 2,3 , and 5), indicating that the region between $\mathrm{V}_{\mathrm{L}}$ and $\mathrm{J}_{\mathrm{L}}$ is deleted from the genome during V-J joining.

\section{Signal joints as a marker for V-J joining during development}

The rearrangement of the chicken $V_{L}$ and $J_{L}$ gene segments occurs by deletion of the region between $V_{L}$ and $\mathrm{J}_{\mathrm{L}}$, and formation of a circular signal joint episome that is detectable after DNA amplification using the polymerase chain reaction (PCR; McCormack et al. 1989). This episome is an unstable genetic element that is not propagated during B-cell development and is not reintegrated into the genome, as demonstrated for the cell lines shown in Figure 2. The presence of the deleted circular episome may therefore be used as a marker for recent gene rearrangements. 


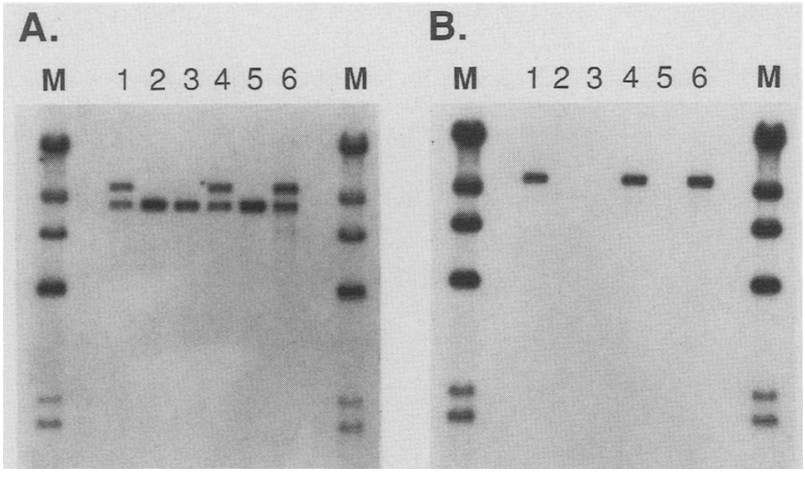

Figure 2. Rearrangement of the $\mathrm{Ig}_{\mathrm{L}}$ locus in bursal lymphoma cell lines. DNA samples from bursal lymphoma cell lines (lanes 1-5) and from bursal lymphocyte DNA of 6-week-old SC chickens (lane 6) were digested with the enzyme Bcll. Cell lines used were 27Ll (lane 1), 28Ll (lane 2), 30L1 (lane 3), 30B3 (lane 4 ), and $41 \mathrm{~L} 1$ (lane 5). Identical Southern blots of these samples were hybridized with the $\mathrm{C}_{\mathrm{L}}$ probe $(A)$ and the $\mathrm{U}_{3}$ probe $(B)$, and the resulting autoradiograms are shown. Hybridization with the $\mathrm{U}_{2}$ probe produced identical results to $B$ (not shown). Size markers (top to bottom: 23.1, 9.4 6.7, 4.4, 2.3, and $2.0 \mathrm{~kb}$ ) were prepared as in Fig. 1.

The bursa and spleen DNA samples from different stages of development that were used for Southern blot analysis of the chicken $\mathrm{Ig}_{\mathrm{L}}$ locus (Fig. 1B) were also analyzed for the presence of the signal joint episome. The DNA samples were subjected to PCR amplification using primers 993 and 994 , and the presence of signal joints was confirmed by specific hybridization of the $\mathrm{U}_{3}$ probe to equal aliquots of the amplified products (Fig. 3A). As shown in Figure 3B, significant hybridization occurred in both splenic- and bursal-amplified DNA at day 15 of embryogenesis, but little hybridization was detected in either tissue at later times during development. Whereas the signal joint episome was detected in additional DNA preparations at later stages (not shown), the high relative abundance of the signal joint episome at day 15 was consistently observed. Despite the differences observed in signal joint products during development, amplification of the same DNAs with primers specific for the histone H2B-IV gene resulted in similar levels of PCR-amplified product (Fig. 3C). Similar results were also obtained with the $\alpha$-tubulin c $\alpha 5$ gene-specific primers (data not shown). In additional experiments, DNA samples were subjected to two separate rounds of PCR amplification to increase the sensitivity for the detection of signal joints. Under these conditions, we were able to detect signal joints in 10- to 12-day embryo tissues from a variety of sources, including liver/spleen, bursa, and bone marrow (data not shown).

The decrease in abundance of DNA encoding an episomal signal joint within the bursa between days 15 and 18 of embryogenesis coincides with a large increase in the number of bursal cells containing an $\operatorname{Ig}_{\mathrm{L}}$ rearrangement (see Fig. 1B). These observations strongly suggest that the increase in Ig-expressing cells during this time
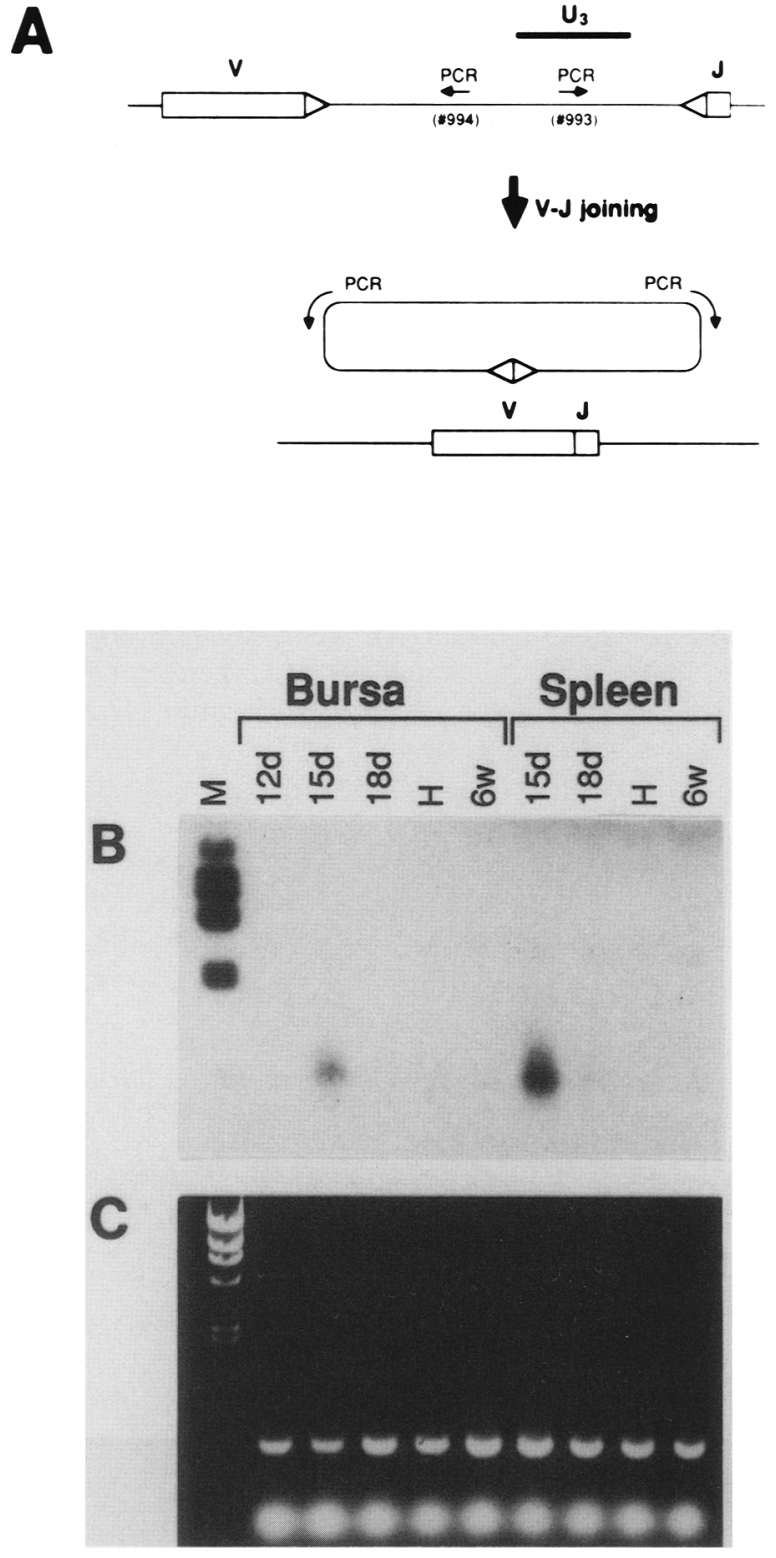

Figure 3. Presence of the signal joint episome during development. (A) Cartoon illustrating detection of the signal joint episome by PCR amplification. The $\mathrm{V}_{\mathrm{L}}$ and $\mathrm{J}_{\mathrm{L}}$-coding segments are indicated by open boxes, and signal sequences are indicated by triangles. The orientation of PCR primers 993 and 994 is shown by arrows, and the $\mathrm{U}_{3}$ hybridization probe is indicated by the solid bar. $(B)$ The DNA samples isolated from embryonic tissues at different stages of development (Fig. 1) were used to amplify signal joints by PCR. Southern blots of equal aliquots of the PCR products were prepared and hybridized with the $\mathrm{U}_{3}$ probe, and the resulting autoradiogram is shown. Size markers (top to bottom: $23.1,9.46 .7,4.4,2.3$, and $2.0 \mathrm{~kb}$ ) were prepared as in Fig. $1 .(C)$ The same DNA samples used to amplify signal joints in $B$ were used to amplify the histone H2B-IV gene. PCR was performed using unique flanking sequence primers. Ten percent of the reaction mix was run on a $1 \%$ agarose gel, stained with ethidium bromide, and photographed. Lanes are as indicated in $B$. In each lane, the upper band is the amplified H2B-IV gene, and the lower band is composed of the remaining nucleotides and primers. 
period results from migration to the bursa and/or clonal expansion of cells with productive $\mathrm{Ig}_{\mathrm{L}}$ rearrangements, rather than further $\operatorname{Ig}_{\mathrm{L}}$ rearrangement within the bursa.

\section{Coding joints of cDNA clones from the bursa at day 18}

Twelve $\operatorname{Ig}_{\mathrm{L}} \mathrm{cDNA}$ clones were isolated from a cDNA library made from bursal lymphocytes of day-18 embryos. Nucleotide sequencing of the $\mathrm{V}$ and $\mathrm{J}$ regions of the cDNA clones revealed seven unique sequences, all with in-frame V-J joints. These V-J junctions are compared to the germ-line sequences of $V_{L}$ and $J_{L}$ in Figure 4A. Germ-line $V_{L}$ and $J_{L}$ sequences were determined after PCR amplification of the $\operatorname{Ig}_{\mathrm{L}}$ alleles from both parental strains of the SC chicken.

At least four of the seven cDNA clones encode V-J joints that had not undergone gene-conversion events. All of these cDNA clones encoded gene-conversion events in other regions of the $\mathrm{V}_{\mathrm{L}}$ gene segment similar to those described previously by Reynaud et al. (1987). An analysis of the gene-conversion events will be reported separately. Six different V-J junction sequences were found in these cDNAs. The exact joining event that created some V-J junctions is impossible to determine, however, due to the repeated TG sequence at the $3^{\prime}$ end of $\mathrm{V}_{\mathrm{L}}$ and at the $5^{\prime}$ end of $\mathrm{J}_{\mathrm{L}}$.

\section{Coding ioints of PCR clones from the bursa during development}

To extend the sequence analysis of chicken V-J joining to earlier stages of embryonic development, we amplified rearranged $\mathrm{Ig}_{\mathrm{L}}$ genes by PCR using primers 1001 and 839 , located $5^{\prime}$ of $V_{L}$ and $3^{\prime}$ of $J_{L}$, respectively. V-J joints were cloned from bursal and spleen DNA isolated at days 10-12 of development and from bursal DNA of day-15 and day-18 embryos. Thirty or more clones were sequenced from each stage of development, and the V-J joints of these clones are shown in Figure 4, B-D. Although several of the clones obtained at 18 days of development contain gene-conversion events involving codons 84 and 86 , the sequence data confirm that both $\mathrm{Ig}_{\mathrm{L}}$ alleles are involved in V-J joining at approximately equal frequencies, as indicated by the sequence polymorphisms between the parental strains of the heterozygous SC chicken at codons $84(\mathrm{C} / \mathrm{G})$ and $86(\mathrm{~A} / \mathrm{G})$.

A large proportion (24 of 44 ) of the clones obtained at day 18 had gene-conversion events at the V-J junction (data not shown) and will be reported separately. Although gene conversion of clone B18-63 resulted in the insertion of 4 nucleotides and a reading frame shift (not shown), it is listed with the other in-frame sequences because the V-J joining event itself was productive. Definitive gene-conversion events were absent from the PCR clones isolated from day-15 bursa and day-10 to day-12 tissues. This result agrees with earlier Southern blot results that indicated significant modification of the rearranged $V_{L}$ gene segment by day 18 of development, but not earlier (Thompson and Neiman 1987).
At least 28 different joining events are represented in the PCR clones, revealing a higher degree of chicken $\operatorname{Ig}_{\mathrm{L}}$ junctional diversity than described previously. The extent of nucleotide deletion from the $V_{L}$ and $J_{L}$ gene segments prior to ligation of the coding joints was as high as 11 nucleotides from $V_{L}$ (in clone B15-17) and 14 nucleotides from $J_{L}$ (in clone B15-37). Such extreme base loss is not observed in day-18 cDNA or PCR sequences, possibly because too many codons are deleted to encode a functional light-chain protein.

A somewhat surprising feature of the V-J junction sequences is the occurrence of an A nucleotide at the $5^{\prime}$ end of some $\mathrm{J}_{\mathrm{L}}$ segments that is not found in the germline sequence (e.g., cDNA 99, B15-28) and a C nucleotide at the $3^{\prime}$ end of some $V_{L}$ segments (e.g., B18-71, B15-13). One sequence has both nucleotides (B15-20). We have speculated that these nucleotides are added to the coding segments during the rearrangement process (McCormack et al. 1989).

\section{Selection of productive V-J joints in the bursa during development}

Whereas few out-of-frame V-I joints are observed in sequences derived from day 18 of development, many nonproductive V-J joints were isolated from the earlier stages (Fig. 4). The percentages of productive versus nonproductive rearrangements cloned from the bursa at different developmental stages are summarized in Table 2. Independent joining events were identified by unique V-J junctions and by gene-conversion events. These numbers may underestimate the actual number of independent joints represented, because many of the junction sequences may be formed by more than one joining event (e.g., B18-06 and B18-65) but are counted only once. The percentages calculated from the total set of $\mathrm{V}-\mathrm{J}$ joints assume that the amplification and cloning efficiencies were equal and that a large number of random events were cloned.

The data summarized in Table 2 show that the proportion of nonproductive V-J joints at the earliest bursal stage examined, days 10-12, approaches the two-thirds expected if V-J joining is random for the nucleotide position of ligation of the $\mathrm{V}_{\mathrm{L}}$ and $\mathrm{J}_{\mathrm{L}}$ gene segments. Similar percentages of out-of-frame joints were also identified in clones isolated from splenic tissue at this developmental stage (Fig. 4D). At successively later stages of bursal development, the percentage of nonproductive joints decreases to $21 \%$ of all joints at day 15 and to $6 \%$ at day 18. These results are consistent with the selection of cells expressing a productive $\mathrm{Ig}_{\mathrm{L}}$ rearrangement for clonal expansion within the bursa of Fabricius during this period of embryonic development.

\section{$V$-I joints of cell lines with two rearranged $\operatorname{Ig}_{L}$ alleles}

The V-J joints made by B-cell lymphomas that rearranged both $\mathrm{Ig}_{\mathrm{L}}$ alleles were also investigated to determine the functional status of their $\mathrm{Ig}_{\mathrm{L}}$ gene rearrange- 


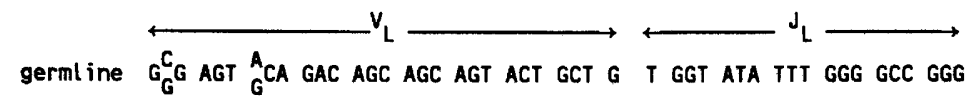

A. 18 day CDNA

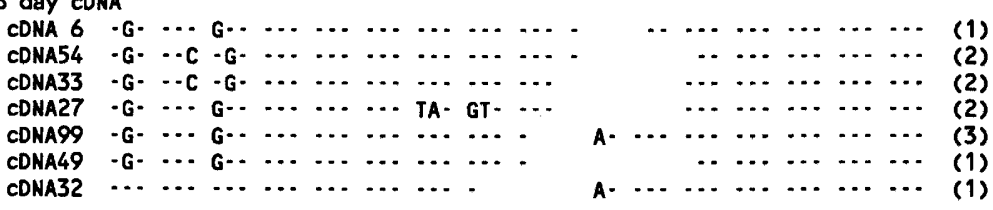

B. 18 day PCR in frame

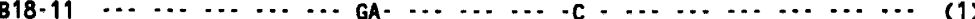

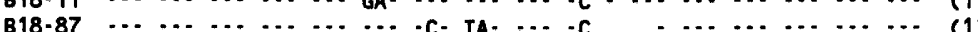

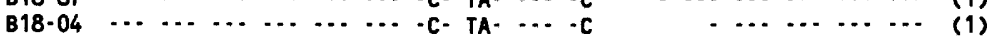

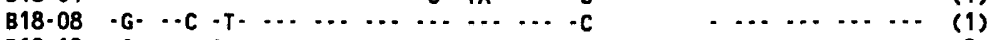

B18-12 $-G \cdot \ldots \cdot G \cdot . \cdots \cdots$

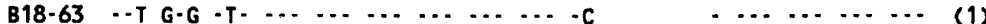

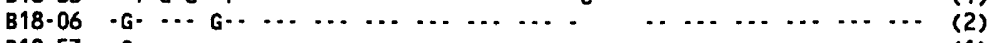

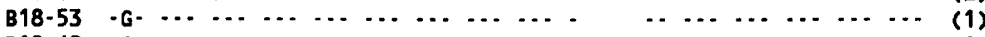

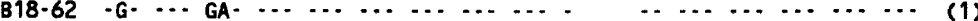

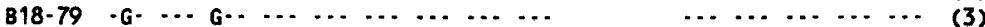

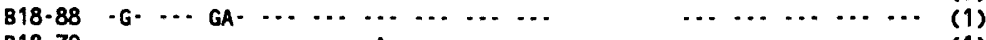

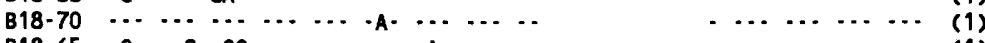

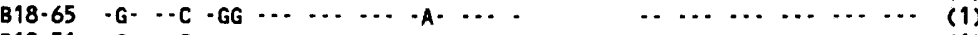

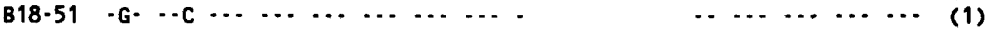

18 day PCR out of frame

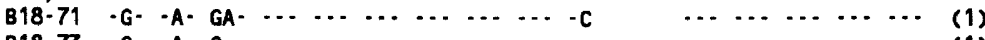

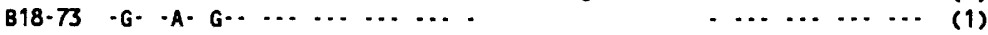

C. 15 day PCR in frame

B15-13 $-G . \cdots 1$...

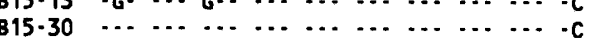

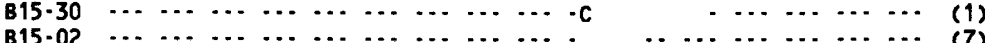

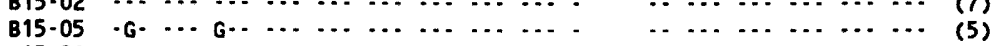

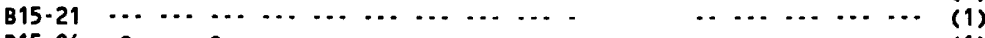

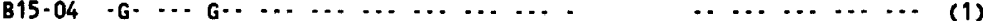

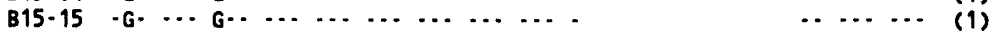

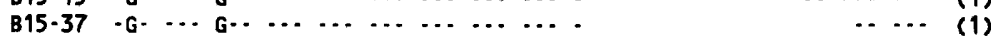

$\begin{array}{lllllllllllllll}B 15-08 & \ldots & \ldots & \ldots & \ldots & \ldots & \ldots & \ldots & \ldots & \ldots & & \ldots & \ldots & \ldots & \ldots\end{array}$

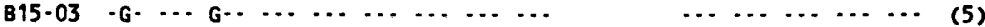

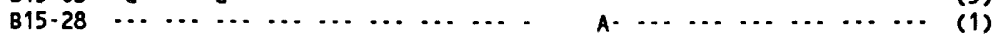

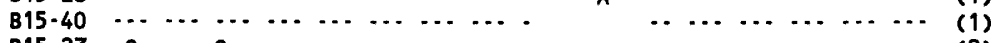

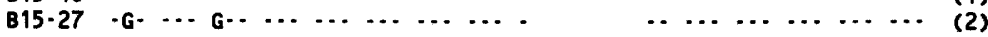

$\begin{array}{llllllllllllll}B 15-41 & G & G & \ldots & G & \ldots & \ldots & \ldots & \ldots & \ldots & \ldots & \ldots & \ldots & \ldots\end{array}$

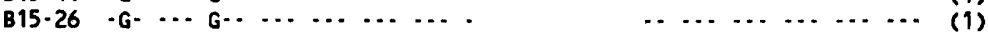

15 day PCR out of frame

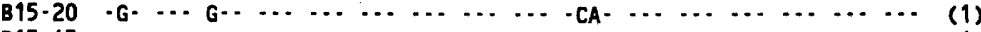

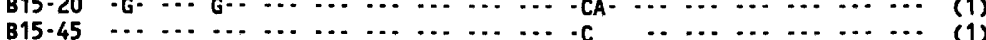

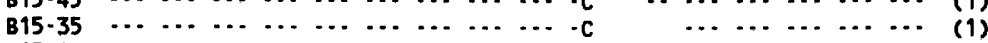

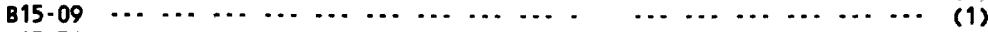

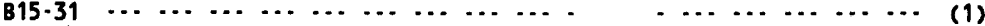

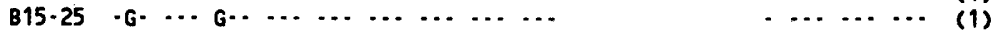

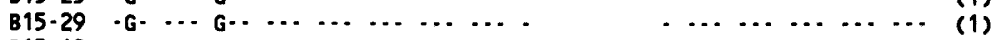

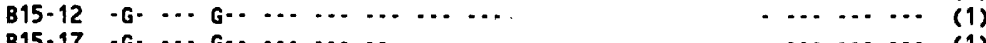

D. 10-12 day PCR in frame

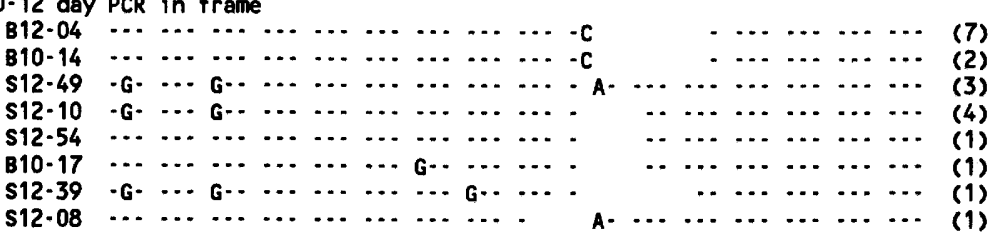

10-12 day PCR out of frame

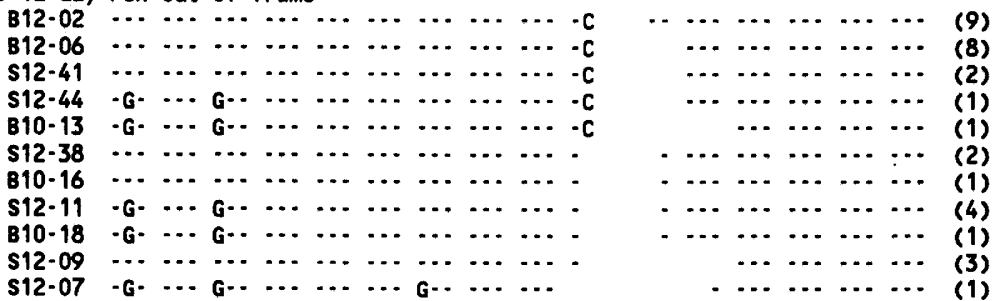

Figure 4. (See following page for legend.) 
Table 2. Percentage of productive versus nonproductive V-I joints cloned from the bursa

\begin{tabular}{llclcc}
\hline & \multicolumn{2}{c}{ Independent V-J joints } & & \multicolumn{2}{c}{ All V-J joints sequenced } \\
\cline { 2 - 3 } \cline { 5 - 6 } Day & productive & nonproductive & & productive & nonproductive \\
\hline $10-12$ & $38 \%(3 / 8)$ & $62 \%(5 / 8)$ & & $33 \%(10 / 30)$ & $67 \%(20 / 30)$ \\
15 & $63 \%(15 / 24)$ & $37 \%(9 / 24)$ & & $79 \%(34 / 43)$ & $21 \%(9 / 43)$ \\
18 & $91 \%(21 / 23)$ & $9 \%(2 / 23)$ & & $94 \%(30 / 32)$ & $6 \%(2 / 32)$ \\
\hline
\end{tabular}

The numbers of productive and nonproductive V-J joints are shown in parentheses. Bursal cDNA clones were included with the PCR clones in the calculations for the day-18 V-J joints.

ments. Rearranged $\mathrm{Ig}_{\mathrm{L}}$ genes were amplified from cell line DNA by PCR and cloned. Clones representing each of the two alleles were distinguished by the presence or absence of the Scal site at the 3' end of the $V_{L}$ gene segment, as determined by restriction enzyme analysis, and pooled colonies for each allele were then used for sequencing. The nucleotide sequences of the V-J junctions are summarized in Figure 5.

The cell line 30L1 has one productive and one nonproductive $\operatorname{Ig}_{\mathrm{L}}$ rearrangement. The productively rearranged allele has a non-germ-line $G$ nucleotide in codon 90 of $V_{L}$ that may be the result of a gene-conversion event and a second gene-conversion event elsewhere in the $\mathrm{V}$ region (not shown). The other allele has the $\mathrm{V}_{\mathrm{L}}$-terminal $\mathrm{C}$ nucleotide at an out-of-frame V-I junction. Additional non-germ-line nucleotides elsewhere in the $V_{L}$ region of this allele (not shown) may be the result of gene conversions, demonstrating that gene conversion may occur in both productively and nonproductively rearranged $\operatorname{Ig}_{\mathrm{L}}$ alleles. These data also rule out the possibility that an out-of-frame V-J joining event is a lethal event by itself.

The cell line $41 \mathrm{~L} 1$ has distinct productive rearrangements at both $\mathrm{Ig}_{\mathrm{L}}$ alleles. It is not known whether both $\mathrm{Ig}_{\mathrm{L}}$ alleles are expressed by $41 \mathrm{Ll}$. Productive rearrangements of nonexpressed alleles of some mammalian Ig loci have been reported (Nottenburg et al. 1987). Both rearranged alleles of $41 \mathrm{~L} 1$ have also undergone gene conversion within $\mathrm{V}_{\mathrm{L}}$ (Fig. 5, and data not shown).

\section{Discussion}

The analysis of $\mathrm{Ig}_{\mathrm{L}}$ rearrangement during B-cell development in the chicken has allowed a detailed characterization of the early stages in avian B-cell differentiation. The exact location and period of active chicken Ig gene rearrangement has not been characterized previously.
Our data demonstrate that most $\mathrm{Ig}_{\mathrm{L}}$ rearrangements occur at or just before day 15 of development, because the amount of the signal joint episome that is detectable during development in bursal and spleen tissue peaks at day 15 (Fig. 3). The fact that both rearranged V-J joints and signal joints can be isolated from extrabursal tissue between days 10 and 15 of development suggests that the bursa is not required for $\operatorname{Ig}_{\mathrm{L}}$ gene rearrangement. These data are consistent with previous studies showing that removal of the bursa anlage at $60 \mathrm{hr}$ of development does not prevent the expression of normal levels of serum Ig or the appearance of $\mathrm{sIg}^{+} \mathrm{B}$ cells in peripheral lymphoid organs (Jalkanen et al. 1983). However, the serum Ig of bursectomized chickens displays extremely limited $\mathrm{Ig}_{\mathrm{L}}$ diversity, as demonstrated on isoelectric focusing gels (Jalkanen et al. 1984). Several recent studies have suggested that this is because the bursa of Fabricius is the site where diversity is generated within rearranged $\mathrm{Ig}_{\mathrm{L}}$ genes by gene conversion (Reynaud et al. 1987; Thompson and Neiman 1987). The sequence data presented in this paper are consistent with this hypothesis. The $\mathrm{Ig}_{\mathrm{L}} \mathrm{cDNA}$ and PCR clones isolated from day- $18 \mathrm{em}$ bryonic bursae demonstrate a high rate of base pair substitution within the $\mathrm{V}_{\mathrm{L}}$ segments.

The data we have obtained concerning chicken $\mathrm{Ig}_{\mathrm{L}}$ rearrangement are consistent with a model in which $\mathrm{Ig}_{\mathrm{L}}$ genes are activated to rearrange during a limited stage of B-cell differentiation. Our data do not support a significant role for feedback mechanisms to prevent rearrangement of both chicken $\mathrm{Ig}_{\mathrm{L}}$ alleles, as proposed for mammalian allelic and isotypic exclusion (Yancopoulos and Alt 1986). Instead, it appears more likely that in developing chicken B cells, the V-J 'recombinase' complex may be present for such a short time (e.g., only one or a few cell cycles) that most prebursal stem cells either fail to rearrange or only rearrange one ${\operatorname{~} g_{L}}_{\text {allele. Only a few }}$

Figure 4. V-J coding joint nucleotide sequences. The nucleotide sequences of the V-J joints $\left(V_{L}\right.$ codons $84-92$ through $\left.J_{L}\right)$ of rearranged genes are compared to the germ-line sequences obtained from the SC chicken. Two nucleotide sequence polymorphisms $(\mathrm{C} / \mathrm{G}$ in codon 84 and $\mathrm{A} / \mathrm{G}$ in codon 86$)$ distinguish the two germ-line alleles in this region. Identity to the top germ-line sequence is indicated by a dash. Rearranged $\operatorname{Ig}_{\mathrm{L}}$ genes were cloned from a day-18 bursal lymphocyte cDNA library $(A)$ and after PCR amplification from embryonic tissues at different stages with the primers 1001 and $839(B-D)$. PCR clones are designated by the tissue of origin $(B$, bursa; S, spleen), day of development, and clone number. The total number of clones with each sequence shown is given in parentheses. Previous work has suggested that Taq polymerase does not cause base addition or deletion, but the misincorporation rate has been estimated to be $2 \times 10^{-4}$ per nucleotide per cycle (Saiki et al. 1988). Consistent with this, we observed several instances of possible misincorporation (e.g., the G substitutions in clones B10-17, S12-39, and S12-07). Misincorporation would be expected to be more common in the day- 10 to day- 12 clones because of the additional amplification required to isolate them. 


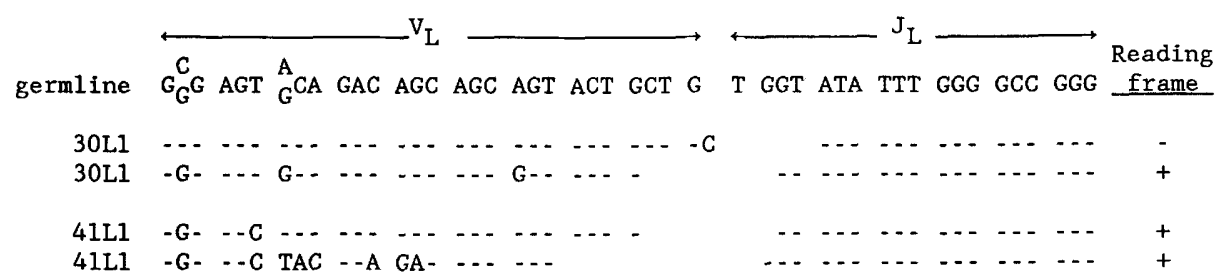

Figure 5. Nucleotide sequences of bursal lymphoma V-J joints. Both rearranged $\operatorname{~} g_{\mathrm{L}}$ alleles were cloned from the bursal lymphoma cell lines $30 \mathrm{Ll}$ and 41L1, following PCR amplification of total cell line DNA with the primers 1001 and 839 . The nucleotide sequences of the V-J joints $\left(\mathrm{V}_{\mathrm{L}}\right.$ codons 84-92 through $\left.\mathrm{J}_{\mathrm{L}}\right)$ of the rearranged genes are compared to the SC chicken germ-line sequences. Identity to the top germ-line sequence is indicated by a dash. (Right) A productive V-J joint is indicated by a plus sign $(+\mid$, and a nonproductive joint is indicated by a minus sign $(-1$.

cells would have time to rearrange both alleles. In chickens, rearrangement of the $\mathrm{Ig}_{\mathrm{L}}$ gene serves primarily to activate gene expression. A large number of cells with productive rearrangements is not required because $\mathrm{Ig}_{\mathrm{L}}$ gene diversity is created by gene conversion subsequent to rearrangement. Consistent with this hypothesis, several experimental approaches have demonstrated that only a few stem cells are required to colonize each of the $10^{4}$ bursal follicles (Le Douarin et al. 1975; Pink et al. 1987; Weill et al. 1986). The presence of two rearranged $\mathrm{Ig}_{\mathrm{L}}$ alleles could potentially complicate the regulation of $\mathrm{Ig}_{\mathrm{L}}$ diversification, because both rearranged alleles appear to be susceptible to gene conversion whether they are in-frame or not. Alternatively, during early lymphoid development, it is possible that one Ig allele in each cell is randomly chosen to undergo rearrangement. One mechanism for such selection would be random inactivation of one $\operatorname{Ig}_{L}$ allele prior to the initiation of rearrangement. This inactivation might be analogous to the way mammalian $\mathrm{X}$ chromosomes undergo inactivation early in development.

As discussed above, previous work has suggested that a major role of the bursa is to provide the necessary microenvironment for the somatic diversification of rearranged V genes (Ratcliffe 1985). Our results provide evidence for an additional role of the bursa during B-cell development, i.e., the selective amplification of lymphocytes with a productive V-J joint at the $\mathrm{Ig}_{\mathrm{L}}$ locus. Between days 15 and 18 of embryogenesis, we observe a large increase in cells containing rearranged $\mathrm{Ig}_{\mathrm{L}}$ genes in the bursa (Fig. 1B). During this period, we also observe a decrease in the relative abundance of the signal joint episome (Fig. 3). These data argue that the increase in bursal lymphoid cells with rearranged $\mathrm{Ig}_{\mathrm{L}}$ genes between days 15 and 18 results from the migration and/or proliferation of cells with rearranged $\operatorname{Ig}_{\mathrm{L}}$ genes, rather than continued $\operatorname{Ig}_{\mathrm{L}}$ gene rearrangement within the bursa. Consistent with this, the failure to detect either signal joint episomes (Fig. 3) or V-J rearrangements (Fig. 1B) within the spleen at day 18 supports the hypothesis that cells that rearrange their $\mathrm{Ig}_{\mathrm{L}}$ gene migrate to the bursa over this time period of development (Houssaint et al. 1976). However, it seems unlikely that selection occurs solely because cells with unproductive rearrangements fail to migrate to the bursa, because significant numbers of cells with out-of-frame rearrangements are found in the bursa between days 10 and 15 of embryogenesis.
By day 18 of embryogenesis, virtually every bursal lymphocyte contains an in-frame V-J joint. Because the somatic diversification of the rearranged $V_{L}$ gene segment has been shown to begin between days 15 and 18 of embryogenesis (Thompson and Neiman 1987), part of the increase in the frequency of productive V-J joints during this period could be the result of 'correction' of out-of-frame joints by gene conversions. However, gene conversion was not observed in any of the $\mathrm{V}-\mathrm{J}$ joints isolated at days 10-15 of embryogenesis. The dramatic increase in the proportion of productive V-J joints during this time period must therefore be due to a bursal selection process. Furthermore, gene conversion may place $\mathrm{V}$-J joints out-of-frame just as frequently as in-frame. Gene-conversion events have been characterized that result in the loss of a productive rearrangement by shifting the reading frame (e.g., PCR clone B18-63, Fig. 4B; cDNA clone 3W-2, Reynaud et al. 1987).

Our data demonstrate that the phenotype of mature chicken B cells does not result from an increase in the precision of V-J rearrangement but from the selection and clonal expansion of cells with productive $\operatorname{Ig}_{\mathrm{L}}$ gene rearrangements. The selective expansion of $\mathrm{B}$ cells with in-frame V-J joints within the bursa could be explained by a novel model, which we present for consideration. In this model, the target structure for positive selection of cells that have made an in-frame $\mathrm{V}-\mathrm{J}$ joint (and a productive $\operatorname{Ig}_{H}$ rearrangement) is the $\mathrm{sIg}$ molecule. If this were the case, selective amplification of cells with productive gene rearrangements could result from antigen-induced proliferation of $\mathrm{sIg}^{+}$cells within the bursa, which is mediated by interaction of germ-line-encoded sIg molecules with a bursal-specific antigen(s). The observation that less junctional diversity is present at later stages of development suggests that specific junctional sequences may also be selected at the protein level by this process because certain amino acids encoded at the V-J junction may be required for antigen recognition. Bursal antigeninduced proliferation would account for the observed exponential growth of embryonic sIg ${ }^{+}$bursal cells (Lydyard et al. 1976) and might also activate the gene-conversion process within the rearranged $\operatorname{Ig}_{\mathrm{L}}$ genes. Exponential growth and gene conversion would continue for a given cell until its sIg receptor no longer reacts with antigen(s) in the embryonic bursal microenvironment. Such a model allows for the selection of B cell tolerance to self-antigens expressed within the bursa 
of Fabricius during the somatic generation of the immune repertoire by gene conversion. Consistent with this model, we have observed that an increasing proportion of $\mathrm{sIg}^{+}$bursal cells cease exponential growth and enter a quiescent state between day 21 of embryogenesis and 2-4 weeks of age, the time at which the mature repertoire is being completed by gene conversion (Thompson et al. 1987).

In summary, we have been able to characterize $\mathrm{Ig}_{\mathrm{L}}$ rearrangement in the chicken during embryonic development. These data have allowed us to characterize further the role of the bursa of Fabricius in avian B-cell differentiation. $\mathrm{Ig}_{\mathrm{L}}$ gene rearrangements occur in many tissues during a limited time period of development, resulting in the generation of $\mathrm{Ig}_{\mathrm{L}}$ junctional diversity. The bursal microenvironment selects B cells with a productive $\mathrm{Ig}_{\mathrm{L}}$ (and $\mathrm{Ig}_{\mathrm{H}}$ ) gene rearrangement and then promotes the gene-conversion process to create the diversity required in the adult immune repertoire.

\section{Methods \\ Chicken strains and cell lines}

The Hyline SC chickens used in these studies result from an $F_{1}$ cross between two inbred $B^{2}$ chicken strains that differ in several restriction enzyme sites around the $\operatorname{Ig}_{\mathrm{L}}$ locus (Thompson and Neiman 1987). Blood samples from both parental strains were obtained from Hyline Incorporated. v-rel-transformed Bcell lines were derived from Hyline SC chickens by infection with reticuloendotheliosis virus strain $\mathrm{T}$ and single-cell cloning (Barth and Humphries 1988). ALV-induced bursal lymphomas were derived as previously described (Thompson et al. 1987).

\section{DNA preparation and Southern blots}

DNA was extracted from single-cell suspensions of bursal and splenic cells at day 15 of embryogenesis and later developmental time points. Due to the small size of the bursa and spleen before day 15 of embryogenesis, DNA samples were prepared from larger tissue fragments. Cell isolation, DNA extraction, and Southern blot methods have been described (Thompson and Neiman 1987). Hybridization probes (Fig. 1A) include the 577-bp ScaI-ScaI $\left(\mathrm{U}_{2}\right)$ and 964-bp ScaI-BamHI $\left(\mathrm{U}_{3}\right)$ genomic fragments between $\mathrm{V}_{\mathrm{L}}$ and $\mathrm{J}_{\mathrm{L}}$ and a $\mathrm{C}_{\mathrm{L}}$ probe $(1.2-\mathrm{kb}$ EcoRI-SalI genomic fragment|. The $\mathrm{V}_{\mathrm{L}}$ probe is a 180-bp KpnIScaI restriction fragment derived from cDNA clone 99.

\section{cDNA library}

A cDNA library was prepared from bursa mRNA of day-18 embryonic Hyline SC chickens in the phage vector $\lambda 345$ (T. St. John, pers. comm.). This vector allows recovery of selected cDNA clones as plasmids by digestion of the phage DNA with $S f i$ and self-ligation of the released plasmid.

\section{PCR}

PCR with the thermostable Taq polymerase (Saiki et al. 1988) was used to rapidly clone multiple independent V-J coding joints from SC chicken splenic and bursal DNA and the two germ-line $\operatorname{Ig}_{\mathrm{L}}$ alleles from erythrocyte DNA of the parental strains, using the following primers, located $5^{\prime}$ of $\mathrm{V}_{\mathrm{L}}$ and $3^{\prime}$ of $\mathrm{J}_{\mathrm{L}}$ respectively:
1001, 5'-GCCGGAATTCGGCAGGAGTGGGCAGGGAGGTGTGGGGAGA-3'
839, 5' -TGGAAGCTTCGGAAGAAAGACCGAGACGAGGTCAGCGACT-3'.

EcoRI and HindIII restriction sites at the $5^{\prime}$ ends of the oligonucleotide PCR primers (underlined) allowed directional cloning into pGEM-3Z. PCR was used to identify the signal joint created during V-J joining, using the following primers, located between $V_{L}$ and $J_{L}$ (Fig. 3A):

993, 5'-GCCGGAA TTCGTCCTCCCCAGCAGTAAGTGGGTCCTCAGG-3' 994, 5'-ATGGAAGCTTGAGTTGGTGAATCTCCTGAGTCACTAGCAA-3'

As controls for single-copy DNA sequences, PCR was performed using primers specific for the unique flanking region of either the H2B-IV gene (Grandy and Dodgson 1987) or the $\alpha$-tubulin c $\alpha 5$ gene (Pratt and Cleveland 1988). In each case, the specificity of the product was confirmed by digestion at internal restriction endonuclease sites (K. Lee and C. Thompson, unpubl.). Oligonucleotides were synthesized on an Applied Biosystems Model 380B DNA synthesizer.

PCR reactions contained $0.2-1 \mu \mathrm{g}$ of DNA template, $1 \mu \mathrm{g}$ of each primer, $0.1 \mathrm{mM}$ of each $\mathrm{dNTP}, 10 \mathrm{mM}$ Tris- $\mathrm{HCl}(\mathrm{pH} \mathrm{8.3)}$, $50 \mathrm{mM} \mathrm{KCl}, 1.5 \mathrm{mM} \mathrm{MgCl}, 0.01 \%$ gelatin, and $2 \mathrm{mM}$ dithiothreitol. PCR reactions were performed with 2.5 units of Taq polymerase (Cetus) in a Perkin-Elmer thermal cycler for 30 cycles, followed by a final $10-\mathrm{min}$ extension reaction. For the amplification of rearranged $\mathrm{Ig}_{\mathrm{L}}$ genes, each cycle included a $1.25-\mathrm{min}$ denaturation step at $94^{\circ} \mathrm{C}$ and a $3-\mathrm{min}$ primer extension step at $72^{\circ} \mathrm{C}$. Whereas 30 cycles of PCR were used to isolate V-I joints from day- 15 and day- 18 tissue, a second round of amplification (total 60 cycles) was required to isolate V-J joints from day-10 to day-12 tissue. For amplification of the germ-line $\mathrm{Ig}_{\mathrm{L}}$ genes from erythrocyte DNA of the SC parental strains, the primer extension step was increased to $5 \mathrm{~min}$. Amplification from the signal joint episome was performed with the addition of a 1 -min annealing step at $55^{\circ} \mathrm{C}$ to each cycle before the primer extension reaction. PCR products for germ-line and rearranged $\operatorname{Ig}_{\mathrm{L}}$ genes were digested with EcoRI and HindIII, cloned into pGEM-3Z, and selected by colony hybridization with the $V_{L}$ probe. Random individual colonies were used for the analysis of multiple V-J coding joints. Colonies were pooled for the cloned germ-line $\operatorname{Ig}_{\mathrm{L}}$ alleles and rearranged alleles of $\mathrm{B}$ cell lymphomas to obtain a consensus sequence free of Taq polymerase errors.

\section{DNA sequencing}

Double-stranded DNA sequencing of both strands was performed using a Sequenase kit according to the supplier's protocols (U.S. Biochemical Corp.). The DNASTAR software package was used for sequence data analysis.

\section{Acknowledgments}

We thank Tom St. John for assistance in preparing the cDNA library in the laboratory of Paul Neiman. We also thank our colleagues Jeff Leiden and Ken Roux for thoughtful review of the manuscript and Paul Neiman, Brian Van Ness, Wesley Dunnick, J. Latham Claflin, Jeff Bonadio, and John Lowe for helpful discussions. We are grateful to Sheila Norton for oligonucleotide syntheses, Jeanelle Pickett for assistance in preparing the manuscript, and Beverly Burck for the preparation of figures. This work was supported, in part, by U.S. Public Health Service Award CA44016 from the National Cancer Institute to E.H.H. 


\section{References}

Barth, C.F. and E.H. Humphries. 1988. A nonimmunosuppressive helper virus allows high efficiency induction of B cell lymphomas by reticuloendotheliosis virus strain T. I. Exp. Med. 167: 89-108.

Engler, P. and U. Storb. 1988. Immunoglobulin gene rearrangement. In Genetic recombination (ed. R. Kucherlapati and G.R. Smith), pp. 667-700. American Society Microbiology, Washington, D.C.

Gollahon, K., J. Hagman, R.L. Brinster, and U. Storb. 1988. Ig $\lambda$-producing $B$ cells do not show feedback inhibition of gene rearrangement. J. Immunol. 141: 2771-2780.

Grandy, D.K. and J.B. Dodgson. 1987. Structure and organization of the chicken H2B histone gene family. Nucleic Acids Res. 15: 1063-1080.

Houssaint, E., M. Belo, and N.M. Le Douarin. 1976. Investigations on cell lineage and tissue interactions in the developing bursa of Fabricius through interspecific chimeras. Dev. Biol. 53: 250-264.

Jalkanen, S., K. Granfors, M. Jalkanen, and P. Toivanen. 1983. Immune capacity of the chicken bursectomized at $60 \mathrm{hr}$ of incubation: Surface immunoglobulin and B-L (Ia-like) antigen-bearing cells. J. Immunol. 130: 2038-2041.

Jalkanen, S., M. Jalkanen, K. Granfors, and P. Toivanen. 1984. Defect in the generation of light-chain diversity in bursectomized birds. Nature 311: 69-71.

Le Douarin, N.M., E. Houssaint, F.V. Jotereau, and M. Belo. 1975. Origin of hemopoietic stem cells in embryonic bursa of Fabricius and bone marrow studied through interspecific chimeras. Proc. Nat1. Acad. Sci. 72: 2701-2705.

Lydyard, P.M., C.E. Grossi, and M.D. Cooper. 1976. Ontogeny of B cells in the chicken. I. Sequential development of clonal diversity in the bursa. I. Exp. Med. 144: 79-97.

McCormack, W.T., L.W. Tjoelker, L.M. Carlson, B. Petryniak, C.F. Barth, E.H. Humphries, and C.B. Thompson. 1989. Chicken $\operatorname{Ig}_{\mathrm{L}}$ gene rearrangement involves deletion of a circular episome and addition of single nonrandom nucleotides to both coding segments. Cell 56: 785-791.

Moore, M.A.S. and J.J.T. Owen. 1966. Experimental studies on the development of the bursa of Fabricius. Dev. Biol. 14: 40-51.

Nottenburg, C., T. St. John, and I.L. Weissman. 1987. Unusual immunoglobulin DNA sequences from the nonexpressed chromosome of mouse normal B lymphocytes: Implications for allelic exclusion and the DNA rearrangement process. $J$. Immunol. 139: 1718-1726.

Pink, J.R.L., O. Vainio, and A.-M. Rijnbeek. 1985. Clones of B lymphocytes in individual follicles of the bursa of Fabricius. Eur. J. Immunol. 15: 83-87.

Pratt, L.F. and D.W. Cleveland. 1988. A survey of the $\alpha$-tubulin gene family in chicken: Unexpected sequence heterogeneity in the polypeptides encoded by five expressed genes. $E M B O$ I. 7: 931-940.

Ratcliffe, M.J.H. 1985. The ontogeny and cloning of B cells in the bursa of Fabricius. Immunol. Today 6: 223-227.

Reynaud, C.-A., V. Anquez, A. Dahan, and J.-C. Weill. 1985. A single rearrangement event generates most of the chicken immunoglobulin light chain diversity. Cell 40: 283-291.

Reynaud, C.-A., V. Anquez, H. Grimal, and J.-C. Weill. 1987. A hyperconversion mechanism generates the chicken light chain preimmune repertoire. Cell 48: 379-388.

Saiki, R.K., D.H. Gelfand, S. Stoffel, S.J. Scharf, R. Higuchi, G.T. Horn, K.B. Mullis, and H.A. Erlich. 1988. Primer-directed enzymatic amplification of DNA with a thermostable DNA polymerase. Science 239: 487-491.
Thompson, C.B. and P.E. Neiman. 1987. Somatic diversification of the chicken immunoglobulin light chain gene is limited to the rearranged variable gene segment. Cell 48: 369378.

Thompson, C.B., E.H. Humphries, L.M. Carlson, C.-L.H. Chen, and P.E. Neiman. 1987. The effect of alterations in myc gene expression on B cell development in the bursa of Fabricius. Cell 51: 371-381.

Tonegawa, S. 1983. Somatic generation of antibody diversity. Nature 302: 575-581.

Weill, J.-C., C.-A. Reynaud, O. Lassila, and J.R.L. Pink. 1986. Rearrangement of chicken immunoglobulin genes is not an ongoing process in the embryonic bursa of Fabricius. Proc. Natl. Acad. Sci. 83: 3336-3340.

Yancopoulos, G.D. and F.W. Alt. 1986. Regulation of the assembly and expression of variable-region genes. Annu. Rev. Immunol. 4: 339-368. 


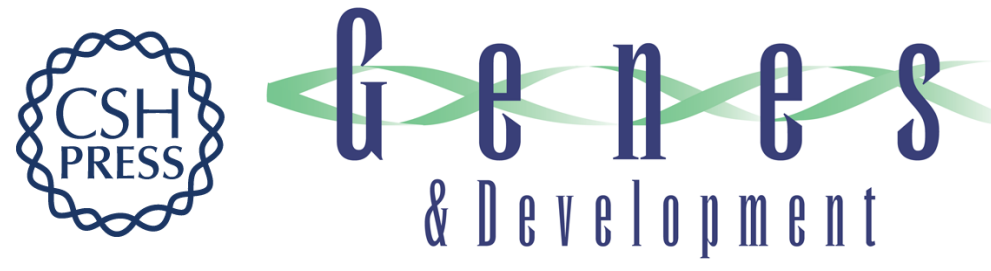

\section{Selection for B cells with productive IgL gene rearrangements occurs in the bursa of Fabricius during chicken embryonic development.}

W T McCormack, L W Tjoelker, C F Barth, et al.

Genes Dev. 1989, 3:

Access the most recent version at doi:10.1101/gad.3.6.838

References This article cites 22 articles, 8 of which can be accessed free at: http://genesdev.cshlp.org/content/3/6/838.full.html\#ref-list-1

License

Email Alerting

Service

Receive free email alerts when new articles cite this article - sign up in the box at the top right corner of the article or click here.

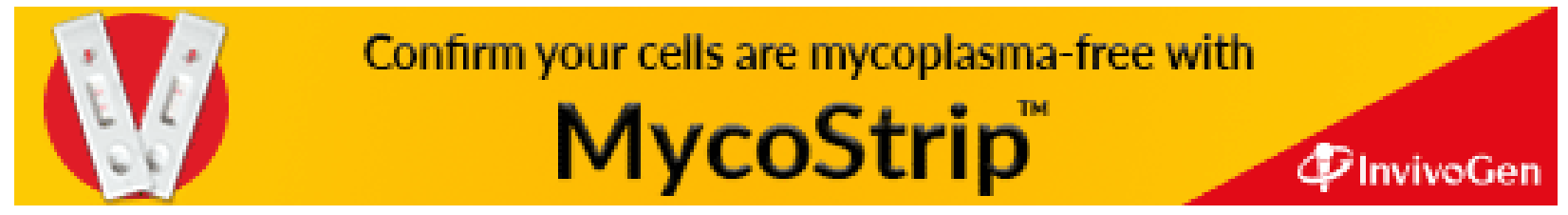

